ПЛАКСЮК І. Ю., аспірант

(Науково-дослідний інститут вивчення проблем злочинності імені академіка B. B. Сташиса)

УДК 343.359.8

DOI https://doi.org/10.32842/2078-3736-2019-6-2-22

\title{
ЗАРУБІЖНИЙ ДОСВІД БОРОТЬБИ З УМИСНИМ ВВЕДЕННЯМ В ОБІГ НА РИНОК НЕБЕЗПЕЧНОЇ ПРОДУКЦІї
}

Статтю присвячено дослідженню кримінального законодавства закордонних країн, що встановлює кримінальну відповідальність за злочини, аналогічні до злочину, передбаченого статтею 227 Кримінального кодексу України «Умисне введення в обіг на ринку України (випуск на ринок України) небезпечної продукції». 3'ясовуються спільні та відмінні риси визначення складу даного злочину у вітчизняному законодавстві та законодавстві деяких закордонних країн.

3'ясовано, що в законодавстві іноземних держав існують різні підходи до розуміння правової природи злочину, аналогічного до умисного введення в обіг на ринку України (випуску на ринок України) небезпечної продукції. Даний злочин має різні назви в законодавстві закордонних держав. На відміну від Кримінального кодексу України, де досліджуваний злочин міститься в розділі «Злочини у сфері господарської діяльності», законодавці інших країн визначають аналогічні злочини як злочини проти громадської безпеки, здоров'я населення, життя і здоров'я особи, економічної діяльності. Отже, родовий об'єкт даного злочину є різним. На відміну від об'єкта, суб'єкт досліджуваного злочину в законодавстві більшості держав є загальним, що $є$ спільною рисою Кримінальних кодексів різних країн світу. Мета злочину не в усіх випадках є обов'язковою ознакою складу злочину. Наслідки даного злочину здебільшого стосуються здоров'я людини.

В Україні, на відміну від деяких інших країн, де передбачено суворі покарання за вчинення досліджуваного злочину, як-от тривалий строк позбавлення волі та навіть смертна кара в Китаї, покарання за вчинення злочину, передбаченого статтею 227 Кримінального кодексу, є досить м'яким, а саме штраф від 500 до 1000 неоподатковуваних мінімумів доходів громадян із позбавленням права обіймати певні посади чи займатися певною діяльністю на строк до трьох років. Автор погоджується з думкою, що така санкція не відповідає суспільній небезпечності даного діяння.

Ключові слова: кримінальне законодавство, небезпечна продукиія, кримінальна відповідальність, введення в обіг небезпечної продукиії, зарубіжний досвід.

The article is devoted to the investigation of the criminal legislation of foreign countries, which establishes criminal liability for crimes similar to the crime envisaged by Article 227 of the Criminal Code of Ukraine "Deliberate putting into circulation in the Ukrainian market (release on the market of Ukraine) of dangerous products". The common and distinctive features between the definition of the composition of a crime in domestic law and the legislation of some foreign countries are clarified. It is found that the laws of foreign countries have different approaches to understanding the legal

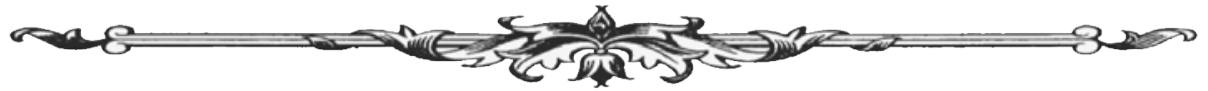


nature of the crime, similar to the deliberate introduction into the market of Ukraine (release to the Ukrainian market) of dangerous products.

This crime has different names in the laws of foreign countries. Unlike the Criminal Code of Ukraine, where the investigated crime is in the section "Crimes in the field of economic activity", legislators of other countries define similar crimes as crimes against public safety, public health, life and health of a person, economic activity. Therefore, the generic object of this crime is different. In contrast to the subject matter, the subject of the crime under investigation in the law of most states is common, which is a common feature of the Criminal Codes of the world. The purpose of the crime is not always a necessary feature of the crime. In most cases, the consequences of this crime relate to human health.

In Ukraine, unlike some other countries where severe penalties are imposed for committing an investigated crime, such as long imprisonment and even the death penalty in China, the punishment for committing a crime under Article 227 of the Criminal Code is rather mild, namely fine from 500 to 1000 non-taxable minimum incomes of citizens with deprivation of the right to occupy certain positions or engage in certain activity for a term of up to three years. The author agrees with the opinion that such a sanction does not correspond to the public danger of the act.

Key words: criminal law, dangerous products, criminal liability, introduction of dangerous products, foreign experience.

Вступ. Науку кримінального права та кримінальне законодавство України про кримінальну відповідальність за умисне введення в обіг на ринку України (випуск на ринок України) небезпечної продукції не можна розглядати ізольовано від того, що відбувається в інших країнах світу.

Проблема випуску на ринок небезпечної продукції $є$ досить дослідженою вітчизняними науковцями, зокрема такими, як: М.І. Хавронюк, О.О. Дудоров, О.В. Звєрєва, Н.В. Наумчук та інші вчені. Проте вітчизняне законодавство все ще потребує більш дієвого механізму притягнення до кримінальної відповідальності осіб, винних у вчиненні даного злочину. Саме тому ця стаття присвячена дослідженню законодавчої практики закордонних країн, досвід яких надзвичайно цінний для українського законодавця.

Постановка завдання. Мета статті - зробити аналіз норм кримінального законодавства закордонних країн, що встановлюють кримінальну відповідальність за випуск на ринок небезпечної продукції.

Результати дослідження. Назва злочину, передбаченого ст. 227 Кримінального кодексу України, по-різному сформульована законодавцями інших держав. Ст. 238 Кримінального кодексу Російської Федерації передбачає кримінальну відповідальність за виготовлення, зберігання, перевезення, або збут товарів та продукції, виконання робіт або надання послуг, що не відповідають вимогам безпеки [1]. Ст. 337 Кримінального кодексу Республіки Білорусь встановлює кримінальну відповідальність за випуск або реалізацію недоброякісної продукції [2]. Ст. 310 Кримінального кодексу Туркменистану встановлює кримінальну відповідальність за випуск чи продаж товарів, надання послуг, що не відповідають вимогам безпеки [3]. Ст. 186 Кримінального кодексу Республіки Узбекистан установлює кримінальну відповідальність за виготовлення, зберігання, перевезення з метою збуту або збут товарів, виконання робіт або надання послуг, що не відповідають вимогам безпеки [4]. Ст. 200 Кримінального кодексу Азербайджанської Республіки передбачено кримінальну відповідальність за обман споживачів або виготовлення та збут неякісної продукції [5]. § 189 гл. 20 Кримінального кодексу Данії передбачає кримінальну відповідальність за продаж чи розповсюдження іншим чином як ліки чи засоби попередження хвороб продуктів, що не підходять для вказаних цілей та, якщо використовуються для даної мети, можуть бути небезпечними для життя чи здоров'я інших осіб [6]. Ст. 288 Кримінального кодексу Албанії встановлено

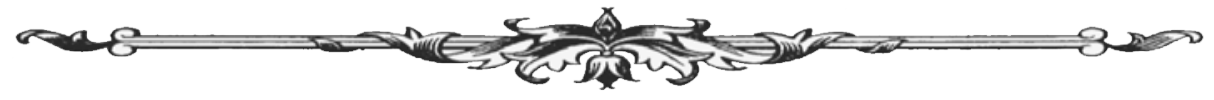


кримінальну відповідальність за виготовлення та продаж продуктів та інших речовин, небезпечних для здоров’я [7]. Ст. 363 Кримінального кодексу Іспанії встановлює кримінальну відповідальність за пропонування на ринку харчових продуктів, що не мають або мають порушені реквізити, встановлені в законах або регламентах про строки придатності та зберігання продуктів; виробництво чи продаж напоїв чи продуктів, призначених для масового споживаня, які є шкідливими для здоров'я; торгівлю зіпсованими товарами; виробництво продуктів, використання яких заборонено та спричиняє шкоду здоров'ю, а також торгівлю ними; приховування чи викрадення товарів, які йдуть на знищення чи дезинфекцію, 3 метою їх продажу [8]. Ст. 140 Кримінального кодексу Китайської Народної Республіки встановлює відповідальність за пересортування та фальсифікацію продукції, видачу підробленої продукції за справжню, другосортної за хорошу або неякісної за якісну виробником, продавцем; ст. 141 - за виробництво та реалізацію підробних лікарських засобів, які можуть завдати шкоди здоров'ю людини; ст. 143 - за виробництво та реалізацію харчової продукції, що не відповідає санітарно-гігієнічним нормам, може спричинити тяжку харчову інтоксикацію або інше серйозне харчове отруєння; ст. 144 - за наявність у харчовій продукції, що виробляється та реалізується, токсичних, шкідливих неїстівних домішків або завідоме знання продавця про факт вмісту у продукції, що реалізується, токсичних, шкідливих, неїстівних речовин; ст. 146 - за виробництво невідповідної ГОСТам із безпеки продукції для життя людини і спеціальним (професійним) стандартам електрообладнання, посуду (ємностей) гідравлічного типу, легкозаймистої та вибухової або іншої невідповідної ГОСТам із безпеки для життя людини та спеціальним (професійним) стандартам продукції, а також реалізацію завідомо невідповідної ГОСТам із безпеки для життя людини та спеціальним (професійним) стандартам продукції, що ппризвели до серйозних наслідків; ст. 147 - за виробництво підробних отрутохімікатів, ветеринарних препаратів, добрив, а також реалізацію завідомо підробних або непридатних до вжитку, таких, що втратили ефективність, отрутохімікатів, ветеринарних препаратів, добрив, насіння, або реалізацію виробником чи продавцем неякісних отрутохімікатів, ветеринарних препаратів, добрив, насіння під виглядом якісних, чим у результаті завдано відносно серйозної шкоди виробництву; ст. 148 - за виробництво невідповідної санітарним нормам косметичної продукції, а також реалізацію завідомо невідповідної санітарним нормам косметичної продукції, що спричинило серйозні наслідки [9].

У Кримінальному кодексі (далі - КК) України ст. 227 міститься в р. VII «Злочини у сфері господарської діяльності». У Російській Федерації (далі - РФ), наприклад, законодавець пішов шляхом зміни спрямованості та змісту кримінально-правової норми, яка за сутністю та змістом є аналогічною до норми національного кримінального законодавства про відповідальність за випуск або реалізацію недоброякісної продукції. Ст. 238 Кримінального кодексу РФ законодавець включив до глави про відповідальність за злочини, які посягають на здоров’я населення [10, с. 12-13]. У кодексах інших держав відповідні статті розміщені в розділах (главах), які передбачають відповідальність за злочини проти:

1) громадської (загальної) безпеки: КК Голандії, Норвегії, Італії, Данії, Франції, Албанії, Польщі, Таїланду;

2) здоров’я населення (громадського, народного здоров'я): КК РФ, Киргизької Республіки, Грузії, Казахстану, Туркменістану, Таджикистану, Вірменії, Білорусі, Литви, Естонії, Молдови, Норвегії, Болгарії, Сербіi;

3) життя і здоров’я особи: КК Бельгії, Швейцарії, Австрії, Швеції, Федеративної Республіки Німеччина, Японії, Республіки Корея, штату Техас США;

4) економічної (господарської) діяльності: КК Латвії, Грузії, Азербайжану, Італії, Болгарії, Китаю [11, с. 37-38].

Отже, доходимо висновку, що в різних країнах законодавець по-різному визначає об’єкт досліджуваного злочину.

У більшості складів злочинів КК закордонних держав не зазначено жодних спеціальних ознак суб' єкта злочину, тому це дає змогу стверджувати, що суб'єкт злочину - загальний. Проте в низці складів злочинів «Випуск або реалізація недоброякісної продукції» КК

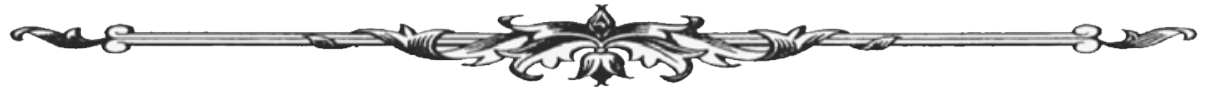


закордонних держав законодавці визначили спеціальні ознаки суб'єкта злочину. Ознаки спеціального суб'єкта злочину є: 1) у ст. 397 КК Туреччини: «особа, яка має дозвіл на продаж медичних препаратів», ст. 400 КК Туреччини: «лікар, фармацевт, особа, що займається професійною діяльністю з охорони здоров'я населення, на заняття якою вимагається отримання офіційної ліцензії»; 2) ст. 360 КК Іспанії: «уповноважений із торгівлі речовинами або продуктами», ч. 2 ст. 362: «фармацевт або технічний керівник легальної лабораторії», ст. 363 КК Іспанії: «виробник, дистриб'ютор, продавець», ч. 1 ст. 364 КК Іспанії: «власник або відповідальний за виробництво на фабриці харчових продуктів»; 3) ст. 204/3 КК Аргентини: «особа, відповідальна за керівництво, адміністрацію, контроль або охорону установ, призначених для продажу ліків», п. 1 ст. 208 КК Аргентини: «особа, яка не володіє званням або повноваженнями для зайняття лікарською практикою», п. п. 2, 3 ст. 208 КК Аргентини: «особа, яка володіє званням або повноваженнями для зайняття лікарською практикою» [12, с. 303].

Відмінними є особливості суб'єктивної сторони складу злочину. В одній групі держав караним є виробництво (виготовлення), зберігання, перевезення відповідної продукції 3 метою збуту (ст. 238 КК РФ, ст. ст. 275 і 276 КК Литви) або передачі (ст. 194 КК Естонії), або випуск з метою збуту (ст. 279 КК Вірменії), тоді як в іншій групі виробництво (виготовлення, переробка) такої самої продукції визнається злочином незалежно від мети (ст. 258 КК Киргизької Республіки, ст. ст. 198 і 246 КК Грузії, ст. ст. 2141 і 216 КК Молдови, ст. 202 КК Латвії, ст. 200.3 КК Азербайджану), як і їі випуск (ст. 269 КК Казахстану, ст. 310 КК Туркменістану, ст. 209 КК Таджикистану, ст. 337 КК Білорусі, ст. 251 КК Грузії, ст. 200.3 КК Азербайджану). Із цього випливає, що в першій із названих груп держав виробництво (виготовлення), зберігання, перевезення відповідної продукції без мети іiі збуту (передачі), а у Вірменії - випуск без мети збуту, не є кримінально караними діяннями.

У багатьох складах злочинів, передбачених КК інших держав світу, наявні факультативні ознаки об'єктивної сторони. Вони стосуються: засобів - шкідливих речовин (ст. 454 КК Бельгії, § 153 КК Норвегії, ст. 364 КК Іспанії), місця - магазину чи іншого місця (ст. 456 КК Бельгіi), часу - під час виробництва, виготовлення або після цього (ст. 362 КК Іспанії) тощо.

Щодо суспільно небезпечних наслідків аналізованих злочинів, то вони, як і у КК пострадянських держав, переважно типові і стосуються фізичної шкоди (винятками є лише ст. ст. 143, 145-148 КК Китаю, де згадуються тяжкі наслідки, особливо тяжкі наслідки і значна, велика й особливо велика шкода виробництву). Прості склади злочину найчастіше побудовані як формальні, а там, де вони є матеріальними, як наслідки згадуються: створення небезпеки для життя та/або здоров’я людини (§ 153 КК Норвегії, § 189 КК Данії, ст. 9 гл. 3 КК Швеції, ст. 2231 КК Франції, ст. ст 361-363 КК Іспанії, § 1 ст. 165 КК Польщі, ст. 236 КК Таїланду, ст. ст. 141 і 143 КК Китаю), «смерть людини чи значна шкода організму або здоров’ю» (§ 157 КК Норвегії), «тяжка шкода здоров’ю людини» (ст. ст. 142 і 145 КК Китаю), «тяжкі наслідки» і «значна шкода виробництву» (ст. ст. 146 і 147 КК Китаю) [11, с. 40-41].

Для притягнення до відповідальності за ст. 227 КК України достатньо встановити, що випуск на ринок України небезпечної продукції вчинений у великих розмірах (таким визнається введення в обіг небезпечної продукції, загальна вартість якої перевищує п'ятсот неоподатковуваних мінімумів доходів громадян). Обурення М.I. Хавронюка викликає той факт, що «законодавець змушує турбуватися суб'єкта відповідного діяння не стільки про те, щоб не випускати на ринок продукцію, небезпечну для здоров'я споживачів, скільки про те, щоб за можливого введення в обіг такої продукції не перейти певну кількісну межу». Але навіть у разі засудження особи за цією статтею їй загрожує на диво м'яке покарання, санкція ст. 227 КК передбачає покарання у виді штрафу від 500 до 1000 неоподатковуваних мінімумів доходів громадян із позбавленням права обіймати певні посади чи займатися певною діяльністю на строк до трьох років. Така санкція абсолютно не відповідає суспільній небезпеці введення в обіг небезпечної продукції. У цьому контексті варто також зазначити, що в низці країн світу за вчинення відповідного діяння передбачено суворі покарання - від тривалого строку позбавлення волі (у Голландії, Норвегії, Аргентині, Польщі, США, Китаї та ін.) до смертної кари (у Китаї) [13, с. 11].

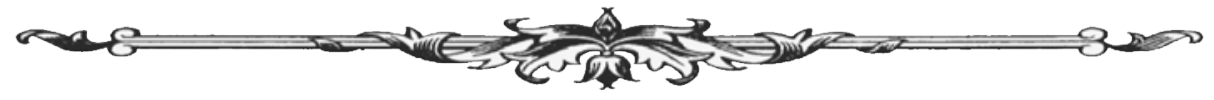


Висновки. Виходячи з наведеного, зазначимо:

1) законодавці інших держав по-різному називають злочин, аналогічний до злочину, передбаченого ст. 227 Кримінального кодексу України;

2) об'єкт даного злочину по-різному визначається у Кримінальних кодексах закордонних країн. Переважно об'єктом визнаються громадська безпека та здоров’я населення, життя і здоров’я особи. У деяких країнах об'єктом є економічна діяльність;

3) спільною рисою складу злочину в різних державах є суб'єкт, що зазвичай є загальним;

4) у деяких країнах кримінально караними є не будь-які дії, пов'язані з виробництвом, зберіганням, перевезенням небезпечної продукції, а лише ті, що були вчинені з метою збуту, тоді як в інших країнах мета не є обов'язковою ознакою складу злочину;

5) закордонні законодавці в деяких випадках надають значення таким ознакам об'єктивної сторони злочину, як засіб, місце, час тощо;

6) деякі склади злочину є формальними, а матеріальні найчастіше мають немайновий характер і полягають у завданні шкоди здоров’ю людини.

\section{Список використаних джерел:}

1. Кримінальний кодекс Російської Федерації. URL: http:/ppt.ru/kodeks. phtml?kodeks=20 (дата звернення: 12.05.2019).

2. Кримінальний кодекс Республіки Білорусь. URL: http://www.pravo.by/document/?gu $\mathrm{id}=3871 \& \mathrm{p} 0=\mathrm{hk} 9900275$ (дата звернення: 12.05.2019).

3. Кримінальний кодекс Туркменистану. URL: http:/www.legislationline.org/ru/ documents/action/popup/id/14380/preview (дата звернення: 12.05.2019).

4. Кримінальний кодекс Республіки Узбекистан. URL: http://lex.uz/docs/111457 (дата звернення: 19.05.2019).

5. Кримінальний кодекс Азербайджанської Республіки. URL: http://continent-online. com/Document/?doc id=30420353\#pos=278;-60 (дата звернення: 19.05.2019).

6. Кримінальний кодекс Данії. URL: http://www.law.edu.ru/norm/norm.asp?normID=124 1524\&subID=100096345,100096366,100096653,100097089\#text (дата звернення: 19.05.2019).

7. Кримінальний кодекс Албанії. URL: http://ugolovnykodeks.ru/2011/11/ugolovnyjkodeks-albanii// (дата звернення: 19.05.2019).

8. Кримінальний кодекс Iспанії. URL: http://aw.edu.ru/norm/norm.asp?normID=124 7923\&subID=100111282,100111284,100111488,100112922,100112946\#text (дата звернення: 19.05.2019).

9. Кримінальний кодекс Китайської Народної Республіки. URL: https:/ukknr.ucoz.ru/ index/0-6 (дата звернення: 26.05.2019).

10. Герасименко С.В. Соціальна обумовленість криміналізації діяння, передбаченого ст. 227 КК України «Випуск або реалізація недоброякісної продукції». Актуальні проблеми сучасної науки в дослідженнях молодих вчених : матеріали Науково-практичної конференції, м. Харків, 24 травня 2008 р. Харків : Вид-во Харк. нац. ун-ту внутр. справ, 2008. С. 12-15.

11. Хавронюк M.І. Відповідальність за порушення права споживачів на безпечність продукції за кримінальними кодексами України та інших держав. Вісник Верховного Суду України. 2011. № 5 (129). С. 34-44.

12. Цюра А. Кримінальна відповідальність за аналогічний до «Випуску або реалізації недоброякісної продукції» КК України злочин у кримінальному законодавстві деяких зарубіжних держав. Вісник Львівського університету. Серія «Юридична». 2007. Вип. 44. C. 295-306.

13. Андрушко А. Проблеми кримінально-правової протидії обігу небезпечних біодобавок в Україні. Науковий вісник Ужгородського національного університету. 2013. Вип. 22. Ч. II. T. 3. C. 9-12.

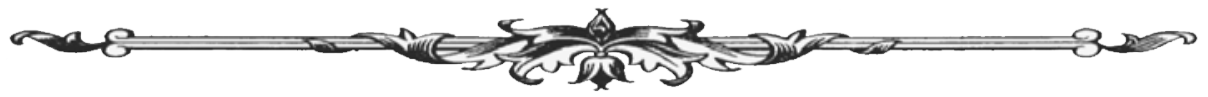

